\title{
УДК: 541.11
}

\section{ПОРИСТЫЕ УГЛЕРОДНЫЕ МАТЕРИАЛЫ, ПОЛУЧЕННЫЕ}

\section{ХИМИЧЕСКОЙ АКТИВАЦИЕЙ ДРЕВЕСИНЫ БЕРЕЗЫ}

\author{
Б.Н. Кузнецов ${ }^{1,2}$, Н.В. Чесноков ${ }^{1,2}$, С.И. Цыганова ${ }^{1}$, Н.М. Микова ${ }^{1}$, И.П. Иванов ${ }^{1}$, \\ Н.М. Иванченко ${ }^{1}$ \\ ${ }^{1}$ Институт химии и химической технологии СО РАН, Красноярск, \\ e-mail: bnk@icct.ru \\ ${ }^{2}$ Сибирский федеральный университет, Красноярск
}

\section{Аннотация}

Установлено, что основными факторами, определяющими выход и удельную поверхность пористых углеродных материалов (ПУМ), получаемых химической активацией древесины березы, являются природа модифицирующего агента и температура пиролиза. Дополнительное раскрытие пористой структуры продукта химической активации древесины происходит на стадии его водной обработки в результате удаления водорастворимых соединений.

Осуществлен подбор условий карбонизации древесины березы, модифицированной фосфорной кислотой, обеспечивающих получение пористых углеродных материалов с удельной поверхностью до $700 \mathrm{~m}^{2} / \Gamma$. ПУМ с наиболее высокой удельной поверхностью (свыше $2560 \mathrm{~m}^{2} /$ ) получен путем водной отмывки продукта карбонизации при $400{ }^{\circ} \mathrm{C}$ модифицированной $\mathrm{H}_{3} \mathrm{PO}_{4}$ древесины березы.

Максимальная удельная поверхность ПУМ, полученных пиролизом древесины березы, модифицированной КОН, достигает $1500 \quad \mathrm{~m}^{2} / \Gamma \quad$ после карбонизации при $800{ }^{\circ} \mathrm{C}$ и последующей отмывки водой.

Модифицирование древесины березы хлоридом цинка смещает начало протекания интенсивных термохимических превращений древесины в 
низкотемпературную область и приводит к увеличению удельной поверхности получаемых ПУМ в 10-25 раз при незначительном повышении их выхода по сравнению с исходной древесиной березы.

\section{Введение}

Производство пористых углеродных материалов (ПУМ) является одним из рациональных направлений утилизации отходов лесозаготовки и переработки древесины. В настоящее время возрастает интерес к получению микропористых сорбентов, способных эффективно сорбировать низкомолекулярные газы и проявлять молекулярно-ситовые свойства при разделении газовых смесей [1-4].

Для получения микропористых углеродных материалов эффективно использование методов химической активации исходного сырья. Они основаны на введении в сырье химических добавок с последующей карбонизацией в инертной среде или в присутствии газообразного окислителя. В качестве химических промоторов используют такие соединения, как $\mathrm{ZnCl}_{2}, \mathrm{Al}_{2} \mathrm{O}_{3}, \mathrm{H}_{3} \mathrm{PO}_{4}$, карбонаты или оксиды щелочных металлов и др. [5-8] При повышенных температурах они ускоряют превращения, которые способствуют удалению из сырья кислорода и других гетероатомов при одновременной карбонизации и развитии пористой структуры получаемого углеродного материала.

Химическая активация позволяет уменьшить энергозатраты при активации сырья, повысить удельную поверхность, а в ряде случаев - выход получаемых ПУМ по сравнению с традиционными методами активации предварительно карбонизированного продукта газообразными реагентами (водяным паром, $\mathrm{CO}_{2}$, кислородом) [9, 10].

На формирование пористой структуры углеродного материала в процессе химической активации влияют разнообразные факторы, такие как природа и 
количество химического реагента, конечная температура и скорость подъема температуры, продолжительность процесса и др. В литературе имеются лишь ограниченные сведения о влиянии указанных факторов на выход и строение ПУМ, получаемых химической активацией древесного сырья [11-13].

Цель настоящей работы - изучение влияния природы химического реагента $\left(\mathrm{KOH}, \mathrm{H}_{3} \mathrm{PO}_{4}, \mathrm{ZnCl}_{2}\right)$, условий термоактивации и водной обработки на выход и текстурные характеристики ПУМ, получаемых из древесины березы.

\section{Экспериментальная часть}

В качестве исходного сырья для получения пористых углеродных материалов использовали воздушно-сухие опилки древесины березы (фракция 0,25-0,5 мм).

Модифицирование древесных опилок проводили путем их пропитки водными растворами КОН, фосфорной кислоты или $\mathrm{ZnCl}_{2}$ в течение 24 часов с последующей сушкой при температуре $102-105{ }^{\circ} \mathrm{C}$ в течение 2-3 суток до постоянного веса. Содержание $\mathrm{KOH}$ и $\mathrm{H}_{3} \mathrm{PO}_{4}$ в древесине берёзы составляло 50 \% мас., а $\mathrm{ZnCl}_{2}-5$ и $10 \%$ мac.

Пиролиз образцов проводили на установке с горизонтальным проточным реактором в токе аргона, подаваемого со скоростью $130 \mathrm{~cm}^{3} /$ мин. Скорость нагрева составляла $10{ }^{\circ} \mathrm{C} /$ мин, конечные температуры нагрева $200{ }^{\circ} \mathrm{C}, 300{ }^{\circ} \mathrm{C}, 400{ }^{\circ} \mathrm{C}, 500{ }^{\circ} \mathrm{C}$, $600{ }^{\circ} \mathrm{C}, 700{ }^{\circ} \mathrm{C}$ и $800{ }^{\circ} \mathrm{C}$, выдержка при конечной температуре - 30 минут. Полученный углеродный материал промывали водой при температуре $60{ }^{\circ} \mathrm{C}$ до нейтральной рН и сушили при температуре $105^{\circ} \mathrm{C}$.

Регистрацию ИК-спектров (FTIR) образцов осуществляли на ИК Фурье спектрометре Vector 22 фирмы Bruker. Образцы для съемки готовили в виде прессованных таблеток, содержащих 2 мг образца в матрице бромистого калия. 
Термогравиметрический анализ выполняли с использованием прибора "Netzsch STA 449F1" в температурном интервале от 30 до $800^{\circ} \mathrm{C}$ со скоростью нагрева образца $5{ }^{\circ} \mathrm{C} /$ мин в атмосфере аргона.

Текстурные характеристики образцов определяли из изотерм адсорбции азота при 77 К с использованием установки ASAP 2420 Micrometrics в диапазоне относительных давлений $\mathrm{P} / \mathrm{P}_{\mathrm{o}}$ 0,005-0,995. Перед измерением образцы выдерживали под вакуумом при $300{ }^{\circ} \mathrm{C}$ в течение 12 часов.

\section{Результаты и обсуждение}

\section{Получение ПУМ из модифицированной КОН древесины березы}

Из литературы известно, что обработка щелочами углеродсодержащих материалов, например ископаемых углей и лигнина, способствует значительному развитию пористой структуры углеродных продуктов, получаемых пиролизом химически модифицированного сырья при повышенной температуре [14-16].

Было изучено влияние соотношения древесина/КОН, температуры термообработки смеси и стадии отмывки углеродных продуктов от водорастворимых веществ на выход и текстурные характеристики получаемых ПУМ.

В результате проведенных исследований установлено, что величина удельной Табл. 1 поверхности и объем пор углеродных материалов, получаемых пиролизом смесей КОН-древесина березы, повышаются при увеличении содержания щелочи в смеси (табл. 1).

При увеличении соотношения древесина/КОН от 1:1 до 1:4 удельная поверхность ПУМ, полученных пиролизом смесей древесина/КОН, увеличивается с 880 до $2050 \mathrm{~m}^{2} /$, а суммарный объем пор от 0,42 до $1,05 \mathrm{~cm}^{3} / \Gamma$. В отсутствие щелочи 
удельная поверхность образца ПУМ, полученного пиролизом древесины березы при $800{ }^{\circ} \mathrm{C}$ составляет $378 \mathrm{~m}^{2} / \Gamma$.

Изотермы адсорбции азота при 77 К на образцах ПУМ, полученных

Рис. 1 пиролизом смесей КОН с древесиной березы (рис. 1), по форме и виду соответствуют, изотермам I типа, что свидетельствует развитой о микропористой текстуре образующихся углеродных материалов [17].

С целью снижения расхода щелочи в процессе химической активации была использована пропитка древесины березы водным раствором КОН. Полученный образец содержал 50 \% мас. КОН.

Было изучено влияние температуры пиролиза этого образца на выход и Рис. 2 и 3 удельную поверхность получаемого твердого продукта (рис. 2 и 3). Как следует из приведенных на рисунке 2 данных, введение в древесину 50 \% мас. КОН повышает в 2-2,5 раза выход твердых продуктов при температурах пиролиза выше $300{ }^{\circ} \mathrm{C}$.

Удельная поверхность твердых продуктов пиролиза исходной древесины и древесины, содержащей 50 \% мас. КОН, слабо зависит от температуры обработки и варьируется от 1 до $30 \mathrm{~m}^{2} / \Gamma$.

С целью удаления водорастворимых веществ и раскрытия пористой структуры твердого продукта применяли водную обработку пиролизованных образцов. Данные о влиянии отмывки твердых продуктов пиролиза модифицированной КОН древесины березы на выход и удельную поверхность пористых материалов приведены на рисунке 3.

Как следует из полученных данных, наибольшее количество водорастворимых веществ присутствует в образцах, пиролизованных при температурах 200 и $300^{\circ} \mathrm{C}$ (рис. 3). Повышение температуры пиролиза свыше $300{ }^{\circ} \mathrm{C}$ приводит к росту выхода ПУМ, очевидно вследствие уменьшения содержания в образцах водорастворимых продуктов. 
Наиболее высокую удельную поверхность (750-1200 м²/г) имеют ПУМ, полученные пиролизом модифицированных КОН образцов древесины березы при температурах $600-800{ }^{\circ} \mathrm{C}$ (рис. 3 ).

Таким образом, водная обработка пиролизованных образцов модифицированной КОН древесины березы способствует дополнительному раскрытию их пористой структуры в результате удаления водорастворимых веществ.

В ИК-спектрах образцов модифицированной КОН древесины березы Рис. 4 наблюдается уменьшение интенсивностей полос поглощения алифатических $\mathrm{CH}_{2}$ и $\mathrm{CH}_{3}$ групп (3000-2800 см с $^{-1}$ с ростом температуры термообработки (рис. 4). Интенсивные полосы в области 1450-850 см${ }^{-1}$ и при $1584 \mathrm{~cm}^{-1}$, наблюдаемые в спектрах всех образцов (вне зависимости от температуры карбонизации), очевидно, соответствуют колебаниям карбонатов и калиевых солей карбоновых кислот [18].

После отмывки водой пиролизованных образцов в их ИК-спектрах (рис. 4) отсутствуют полосы поглощения, относящихся к колебаниям соединений калия, причем, с ростом температуры термообработки наблюдается уменьшение интенсивностей всех полос поглощения. Наличие полос поглощения при 1700 и 1300-1040 см ${ }^{-1}$ свидетельствует о присутствии в составе образцов кето-эфирных соединений, содержание которых заметно уменьшается в образцах, пиролизованных при температурах выше $500{ }^{\circ} \mathrm{C}[18,19]$.

\section{Модификация древесины березы $\mathrm{H}_{3} \mathrm{PO}_{4}$}

Как и в случае ПУМ, полученных из модифицированной КОН древесины Рис. 5 березы, в присутствии фосфорной кислоты наблюдается возрастание выхода углеродного продукта при температурах карбонизации выше $300{ }^{\circ} \mathrm{C}$ (рис. 5 А). Однако для модифицированных $\mathrm{H}_{3} \mathrm{PO}_{4}$ образцов существенный рост удельной 
поверхности (500-700 $\left.\mathrm{m}^{2} / \Gamma\right)$ наблюдается только при температурах пиролиза $700-800{ }^{\circ} \mathrm{C}$ (рис. 5Б).

Проведенный рентгенофлуориесцентный анализ образцов показал, что с ростом температуры карбонизации наблюдается заметное уменьшение содержания фосфора в полученных углеродных материалах. Так, после пиролиза при $800{ }^{\circ} \mathrm{C}$ содержание фосфора в ПУМ на порядок меньше, чем в исходном образце. Это свидетельствует о термической нестабильности фосфорсодержащих соединений и удалении их в виде летучих продуктов при термообработке. Это очевидно способствовует формированию развитой пористой структуры углеродного материала при высокотемпературной обработке. Таким образом, модификация древесины фосфорной кислотой повышает выход и удельную поверхность получаемых углеродных материалов.

Водная обработка пиролизованных образцов была использована для удаления водорастворимых соединений и раскрытия пористой структуры твердых продуктов, полученных пиролизом модифицированной $\mathrm{H}_{3} \mathrm{PO}_{4}$ древесины березы. Обнаружено, что с повышением температуры пиролиза этих образцов от 200 до $800{ }^{\circ} \mathrm{C}$ наблюдается некоторое увеличение выхода отмытых водой ПУМ в то время, как в случае исходной древесины выход твердого продукта резко снижается с ростом Рис. 6 температуры пиролиза (рис. 6). При температурах пиролиза 600-800 드워од ПУМ из модифицированной древесины березы выше, чем из исходной.

С ростом температуры пиролиза содержание водорастворимых веществ в образцах ПУМ из модифицированной $\mathrm{H}_{3} \mathrm{PO}_{4}$ древесины березы уменьшается и после обработки при $800{ }^{\circ} \mathrm{C}$ полученный твердый продукт практически нерастворим в воде.

Отмывка водой образцов ПУМ из модифицированной $\mathrm{H}_{3} \mathrm{PO}_{4}$ древесины березы приводит к существенному повышению их удельной поверхности. 
Максимальная удельная поверхность (2560 $\left.\mathrm{M}^{2} \cdot \Gamma^{-1}\right)$ наблюдается для образца, полученного при $400{ }^{\circ} \mathrm{C}$ (рис. 2 Б). Одной из причин высокой удельной поверхности этого образца может являться удаление водорастворимых фосфорсодержащих соединений в процессе отмывки водой, о чем свидетельствуют данные рентгенофлуориесцентного и ИК спектрального (рис. 7) анализов образца. Снижение удельной поверхности образцов ПУМ, полученных при температурах пиролиза выше $500^{\circ} \mathrm{C}$, может быть вызвано образованием нерастворимых в воде продуктов, блокирующих его поры.

ИК-спектры образцов, полученных термообработкой содержащей $\mathrm{H}_{3} \mathrm{PO}_{4}$ древесины березы в интервале температур 25-500 ${ }^{\circ} \mathrm{C}$, имеют схожий характер (рис. 7). Интенсивное поглощение в области 3600-2000 $\mathrm{cm}^{-1}$ свидетельствует о наличии ОН-групп, включая $\mathrm{P}-\mathrm{OH}$ группы, и небольшого количества алифатических метильных и метиленовых групп. Полоса поглощения указывает на присутствие $\mathrm{C}=\mathrm{O}$ связей. Поглощение в области $1400-980 \mathrm{~cm}^{-1}$ вероятно обусловлено валентными колебаниями связей $\mathrm{C}-\mathrm{O}, \mathrm{C}-\mathrm{C}, \mathrm{P}-\mathrm{O}-\mathrm{C}$ или алкилзамещенных и арилзамещенных фосфатных групп и деформационными колебаниями $\mathrm{CH}_{2}$ и $\mathrm{CH}_{3}$ групп $[19,20]$. В спектрах образцов 6-8, полученных при температурах обработки 600,700 и $800{ }^{\circ} \mathrm{C}$, интенсивность полос поглощения заметно уменьшается. В целом, результаты ИК-спектроскопического исследования свидетельствуют о прогрессирующем удалении различных функциональных групп при повышении температуры пиролиза.

Интенсивность полос поглощения различных функциональных групп в ИКспктрах также резко уменьшается после водной отмывки термообработанных образцов (рис. 7), что свидетельствует об удалении водорастворимых соединений, содержащих группы P-OH, P-O-C и др. Наличие в ИК-спектрах водных вытяжек полос поглощения фосфор-содержащих групп является косвенным подтверждением 
предположения о том, что повышение удельной поверхности отмытых в воде ПУМ обусловлено дополнительным раскрытием их пористой структуры в результате удаления фосфорсодержащих веществ.

Модификаџия древесинь березы $\mathrm{ZnCl}_{2}$

Табл. 2

Изучено влияние содержания введенного в древесину березы $\mathrm{ZnCl}_{2}$ и температуры пиролиза на выход и удельную поверхность получаемых ПУМ (табл. 2).

Основное уменьшение выхода ПУМ из исходной древесины березы происходит в интервале температур $200-400^{\circ} \mathrm{C}$, а для образцов древесины, модифицированной хлоридом цинка - в более узком интервале $200-300^{\circ} \mathrm{C}$. В интервале температур пиролиза $400-800{ }^{\circ} \mathrm{C}$ выход ПУМ из содержащей $\mathrm{ZnCl}_{2}$ древесины березы примерно в 1,5 раза выше, чем из исходной древесины. При этом вариация содержания хлорида цинка в древесине от 5 до 10 мас\% практически не влияет на выход ПУМ.

Величина удельной поверхности ПУМ существенно изменяется в процессе пиролиза модифицированной $\mathrm{ZnCl}_{2}$ древесины (табл. 2). В то время как для ПУМ из исходной древесины она достигает лишь $27 \mathrm{~m}^{2} / \Gamma$ при температуре пиролиза $800{ }^{\circ} \mathrm{C}$, величина удельной поверхности ПУМ, полученного в аналогичных условиях из древесины, содержащей $5 \%$ мас. $\mathrm{ZnCl}_{2}$ составляет $300 \mathrm{M}^{2} /$ г. ПУМ с максимальной величиной удельной поверхности $\left(670 \mathrm{~m}^{2} / \Gamma\right)$ получен пиролизом при температуре $700^{\circ} \mathrm{C}$ образца древесины, содержащей $10 \%$ мас. $\mathrm{ZnCl}_{2}$. Таким образом, химическая активация древесины березы хлоридом цинка способствует увеличению выхода и удельной поверхности получаемых ПУМ. Причем, с повышением содержания хлорида цинка в древесине березы выход углеродного остатка практически не меняется, а величина удельной поверхности возрастает в 1,5-2 раза.

Согласно результатам теромогравиметрического исследования, в присутствии $\mathrm{ZnCl}_{2}$ заметно снижается начальная температура и интенсивность процессов 
термохимических превращений древесины березы. Наиболее высокая скорость термодеструкции исходной древесины березы наблюдается при $330{ }^{\circ} \mathrm{C}$, а в случае образцов модифицированной древесины - при $290^{\circ} \mathrm{C}$ для содержания $\mathrm{ZnCl}_{2} 5$ \% мас. и при $235{ }^{\circ} \mathrm{C}$ - для $10 \%$ мас. $\mathrm{ZnCl}_{2}$.

Данные элементного анализа и ИК-спектроскопического исследования свидетельствует о том, что заметное изменение химического состава исходной древесины березы начинает происходить при температуре пиролиза $300{ }^{\circ} \mathrm{C}$, a модифицированной $\mathrm{ZnCl}_{2}$ древесины - при $200{ }^{\circ} \mathrm{C}$. По-видимому, добавки $\mathrm{ZnCl}_{2}$ способствуют интенсификации процессов декарбоксилирования, декарбонилирования и ароматизации при повышенных температурах. При этом заметно возрастают величины отношения $\mathrm{C} / \mathrm{O}$ и $\mathrm{C} / \mathrm{H}$ и происходит развитие пористой структуры углеродного продукта.

Таким образом, модифицирование древесины березы хлоридом цинка приводит к смещению начала протекания интенсивных термохимических превращений древесины в низкотемпературную область, некоторому повышению выхода углеродного продукта и к увеличению его удельной поверхности (в 10-25 раз по сравнению с ПУМ из исходной древесины березы).

\section{Заключение}

Установлено влияние природы химического промотора, условий процесса пиролиза древесины березы, модифицированной $\mathrm{H}_{3} \mathrm{PO}_{4}, \mathrm{KOH}$ и $\mathrm{ZnCl}_{2}$, а также водной обработки продукта карбонизации химически модифицированной древесины на выход и текстурные характеристики получаемых ПУМ.

Величина удельной поверхности и объема пор ПУМ, получаемых пиролизом при $800{ }^{\circ} \mathrm{C}$ смесей КОН-древесина березы, повышается при увеличении содержания щелочи в смеси. Удельная поверхность ПУМ увеличивается с $880 \mathrm{~m}^{2} / \Gamma$ до $2050 \mathrm{~m}^{2} / \Gamma$, а 
суммарный объем пор от 0,42 до $1,05 \mathrm{~cm}^{3} /$ г. при увеличении массового соотношения древесина/КОН от 1:1 до 1:4. При температуре $800{ }^{\circ} \mathrm{C}$ гидроксид калия находится в расплавленном состоянии, что способствует протеканию частичной газификации углеродного продукта с преимущественным образованием пор размером около 2 нм.

При содержании КОН в древесине 50 \% мас. не удается развть пористую структуру получаемых ПУМ даже при высоких температурах пиролиза (600-800 $\left.{ }^{\circ} \mathrm{C}\right)$. Однако удаление из них водорастворимых соединений, вероятно присутствующих в виде карбонатов и калиевых солей карбоновых кислот, приводит к возрастанию удельной поверхности ПУМ до 750-1200 м²/г.

В случае ПУМ, полученных из древесины березы, модифицированной 50 \% мас. $\mathrm{H}_{3} \mathrm{PO}_{4}$, существенный рост удельной поверхности $\left(500-700 \mathrm{~m}^{2} / \Gamma\right)$ наблюдается при температурах пиролиза $700-800{ }^{\circ} \mathrm{C}$. Удаление растворимых фосфорсодержащих соединений после обработки этих ПУМ водой приводит к значительному увеличению их удельной поверхности (до 2560 м²/г для образца, пиролизованного при $\left.400{ }^{\circ} \mathrm{C}\right)$.

Химическая активация древесины березы 5 и $10 \%$ мас. $\mathrm{ZnCl}_{2}$ способствует увеличению выхода получаемых ПУМ при температурах пиролиза $400-800{ }^{\circ} \mathrm{C}$. В присутствии $\mathrm{ZnCl}_{2}$ заметно (примерно на $90{ }^{\circ} \mathrm{C}$ ) снижается начальная температура и интенсивность процессов термохимических превращений древесины березы.

Удельная поверхность ПУМ из древесины, содержащей 5 \% мас. $\mathrm{ZnCl}_{2}$ достигает $300 \mathrm{~m}^{2} / \Gamma$ при температуре пиролиза $800{ }^{\circ} \mathrm{C}$, а при содержании $\mathrm{ZnCl}_{2} 10 \%$ мас. $-670 \mathrm{~m}^{2} / \Gamma$ при температуре пиролиза $700{ }^{\circ} \mathrm{C}$.

Таким образом, модифицирование древесины березы $\mathrm{ZnCl}_{2}$ приводит к интенсификации процессов термохимических превращений древесины, увеличению выхода ПУМ в 1,5 раза и их удельной поверхности в 10-25 раз. 
Работа выполнена при финансовой поддержке Министерства образования и науки Российской Федерации (проект RFMEFI60714X0031).

\section{Литература}

1. Lozano-Castello D., Alcaniz-Monge J., Cazorla-Amoros D., Linares-Solano A., Zhu W., Kapteijn F., Moulijn J.A. // Carbon. 2005. V. 43. P. 1643.

2. Bello G, Garcia R, Arriagada R, Sepulveda-Escribano A, Rodriguez-Reinoso F. // Microporous and Mesoporous Materials. 2002. V.56. P.139.

3. Babel K., Janasiak D., Jurewicz K. // Carbon. 2012. V. 50. P. 5017.

4. Fatehi A.I., Loughlin K.F., Hassan M.M. // Gas Separation Purif. 1995. V.9. P. 199.

5. Lillo-Rodenas M.A, Marco-Lozar J.P, Cazorla-Amoros D, Linares-Solano A. // J Anal. Appl. Pyrolysis 2007. V.80. P.166.

6. Чесноков Н.В., Микова Н.М., Иванов И.П., Кузнецов Б.Н. // Журнал сибирского федерального университета. Химия. 2014. Т. 1. С. 42.

7. Кузнецов Б.Н., Чесноков Н.В., Микова Н.М., Наймушина Л.В., Павленко Н.И., Селютин Г.Е. // Химия в интересах устойчивого развития. 2002. Т. 10. С. 421.

8. Girgis B.S., El-Hendawy A.N.A. // Microporous and Mesoporous Materials. 2002. V. 52. P. 105.

9. Kushwaha S., Sreelatha G., Padmaja P. // J. Porous Mater. 2013. V. 20. P. 21.

10. Molina-Sabio M., Gonzalez M.T., Rodrigues-Reinoso F., Sepulveda-Escribano A. // Carbon. 1996. V.34. P. 505.

11. Tay T., Ucar S., Karagoz S. // J. Hazard Mater. 2009. V. 165. P. 481.

12. Nakagawa Y., Molina-Sabio M., Rodríguez-Reinoso F. Modification of the porous structure along the preparation of activated carbon monoliths with $\mathrm{H}_{3} \mathrm{PO}_{4}$ and $\mathrm{ZnCl}_{2}$ // Microporous and Mesoporous Materials. 2007. V. 103. P. 29.

13. Babel K, Jurewicz K. // Carbon. 2008. V. 46. P.1948. 
14. Paris O., Zollfrank C., Zickler G.A. // Carbon. 2005. V. 43. N. 1. P. 53.

15. Шендрик Т.Г., Тамаркина Ю.В., Хабарова Т.В., Кучеренко В.А., Чесноков Н.В., Кузнеиов Б.Н. // Химия твердого топлива. 2009. № 5. С. 51.

16. Siminova V.V., Shendrik T.G., Chesnokov N.V., Kuznetsov B.N. // Journal of Siberian Federal University. Chemistry. 2008. N3. P. 215.

17. Грэг С., Синг К. Адсорбция, удельная поверхность, пористость. М: Мир, 1984. $306 \mathrm{c}$.

18. Zhou J-H., Sui Z-J., Zhu J., Li P., Chen D., Dai Y-Ch., Yuan W-K. // Carbon. 2007. V. 45. P. 785.

19. Никаниси К. Инфракрасные спектры и строение органических соединений. М.: Мир, 1965. 319 с.

20. Миронов B.A., Янковский С.A. Спектроскопия в органической химии. М.: Химия, 1985. $232 \mathrm{c}$. 
Текстурные характеристики ПУМ, полученных термообработкой смеси древесины березы с КОН при $800^{\circ} \mathrm{C}$

\begin{tabular}{|c|c|c|c|c|c|}
\hline Образец & $\begin{array}{c}\text { Массовое } \\
\text { отношение } \\
\text { древесина/КОН }\end{array}$ & $\begin{array}{c}\text { Удельная } \\
\text { поверхность, } \\
\text { Худ., } \mathrm{M}^{2} / \Gamma\end{array}$ & $\begin{array}{c}\text { Суммарный } \\
\text { объём пор, } \\
\mathrm{V}_{\text {пор }} /\end{array}$ & $\begin{array}{c}\text { Объём } \\
\text { микропор, } \\
\mathrm{V}_{\text {микро, }} \\
\text { см }^{3} / \Gamma\end{array}$ & $\begin{array}{c}\text { Средняя } \\
\text { ширина } \\
\text { пор D, } \\
\text { нм }\end{array}$ \\
\hline 1 & $1: 1$ & 880 & 0,42 & 0,31 & 2,19 \\
2 & $1: 2$ & 963 & 0,48 & 0,33 & 2,14 \\
3 & $1: 3$ & 1338 & 0,69 & 0,40 & 2,08 \\
& $1: 4$ & 2050 & 1,05 & 0,24 & 2,16
\end{tabular}


Таблица 2

Выход и удельная поверхность углеродного продукта из древесины березы

\begin{tabular}{|l|c|c|c|c|c|c|}
\hline \multirow{2}{*}{$\begin{array}{c}\text { Температура } \\
\text { пиролиза, } \\
{ }^{\circ} \mathrm{C}\end{array}$} & \multicolumn{3}{|c|}{ Выход, \% мас. } & \multicolumn{3}{|c|}{ Удельная поверхность, ${ }^{2} / \Gamma$} \\
\cline { 2 - 6 } & $\begin{array}{c}\text { Исходная } \\
\text { древесина }\end{array}$ & $\begin{array}{c}\text { Модифи- } \\
\text { цированная } \\
5 \% \mathrm{ZnCl}_{2}\end{array}$ & $\begin{array}{c}\text { Модифици- } \\
\text { рованная } \\
10 \% \mathrm{ZnCl}_{2}\end{array}$ & $\begin{array}{c}\text { Исходная } \\
\text { древесина }\end{array}$ & $\begin{array}{c}\text { Модифи- } \\
\text { цированная } \\
5 \% \mathrm{ZnCl}_{2}\end{array}$ & $\begin{array}{c}\text { Модифици- } \\
\text { рованная } \\
10 \% \mathrm{ZnCl}_{2}\end{array}$ \\
\hline отсутствут & 100,0 & 100,0 & 100,0 & 0 & 0 & 0 \\
200 & 93,4 & 76,5 & 69,6 & 0,6 & 1,5 & 0,7 \\
300 & 58,5 & 42,9 & 41,3 & 2,0 & 1,9 & 1,1 \\
400 & 27,7 & 41,5 & 36,6 & 6,0 & 3,2 & 1,8 \\
500 & 22,3 & 34,2 & 33,5 & 10,9 & 25,8 & 281,0 \\
600 & 21,9 & 30,0 & 30,5 & 30,7 & 208,8 & 419,0 \\
700 & 20,6 & 30,0 & 29,0 & 16,2 & 268,5 & 666,0 \\
800 & 19,8 & 26,0 & 27,4 & 27,2 & 296,1 & 474,0
\end{tabular}




\section{Подписи к рисункам}

Рис. 1. Изотермы адсорбции азота (77К) на образцах ПУМ, полученных пиролизом смесей древесина березы-КОН с различным соотношением компонентов $(1-1: 1 ; 2-1: 2 ; 3-1: 3 ; 4-1: 4)$

Рис. 2. Влияние температуры пиролиза на выход твердого продукта из исходной древесины березы (1) и древесины, модифицированной 50 \% мас. КОН (2)

Рис. 3. Влияние температуры пиролиза исходной древесины березы (1) и древесины, содержащей 50 \% мас. КОН (2) на выход (А) и удельную поверхность (Б) отмытого водой пористых материалов

Рис. 4. ИК спектры твердых продуктов, полученных пиролизом содержащей 50 \% КОН древесины березы до $(1,2,3)$ и после $(4,5,6)$ водной обработки. Температура пиролиза $25^{\circ} \mathrm{C}(1,4), 400{ }^{\circ} \mathrm{C}(2,5), 800{ }^{\circ} \mathrm{C}(3,6)$

Рис. 5. Влияние температуры пиролиза исходной древесины березы (1) и древесины, модифицированной $\mathrm{H}_{3} \mathrm{PO}_{4}(2)$ на выход (А) и удельную поверхность (Б) твердого продукта

Рис. 6. Влияние температуры пиролиза исходной древесины березы (1) и древесины, модифицированной $\mathrm{H}_{3} \mathrm{PO}_{4}(2)$ на выход (А) и удельную поверхность (Б) отмытого водой углеродного материала

Рис. 7. ИК спектры твердых продуктов, полученных пиролизом содержащей $\mathrm{H}_{3} \mathrm{PO}_{4}$ древесины березы до $(1,2,3)$ и после $(4,5,6)$ водной обработки. Температура пиролиза $25^{\circ} \mathrm{C}(1,4), 400{ }^{\circ} \mathrm{C}(2,5), 800{ }^{\circ} \mathrm{C}(3,6)$ 


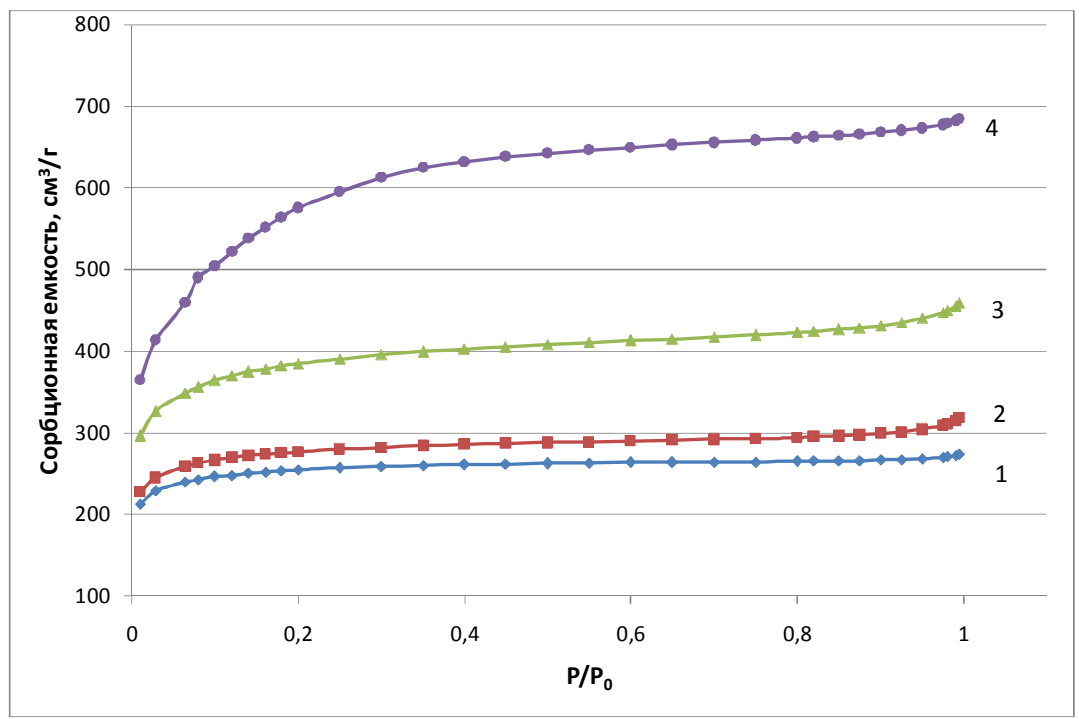

Puc. 1

Кузнецов и др. 


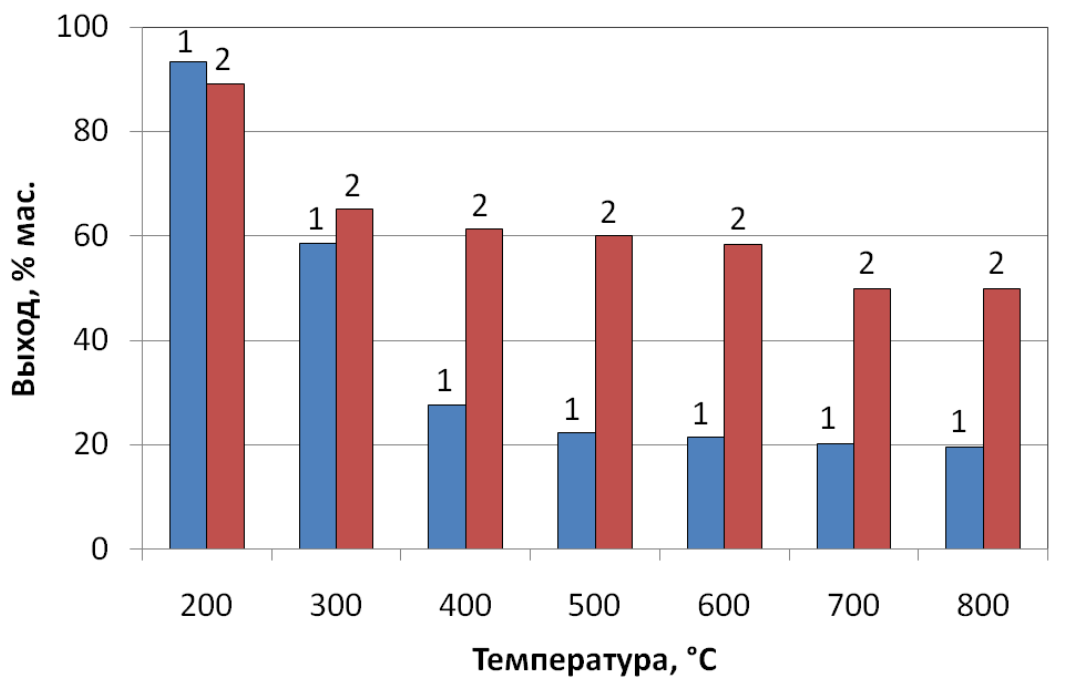

Рис. 2

Кузнецов Б.Н. и др 

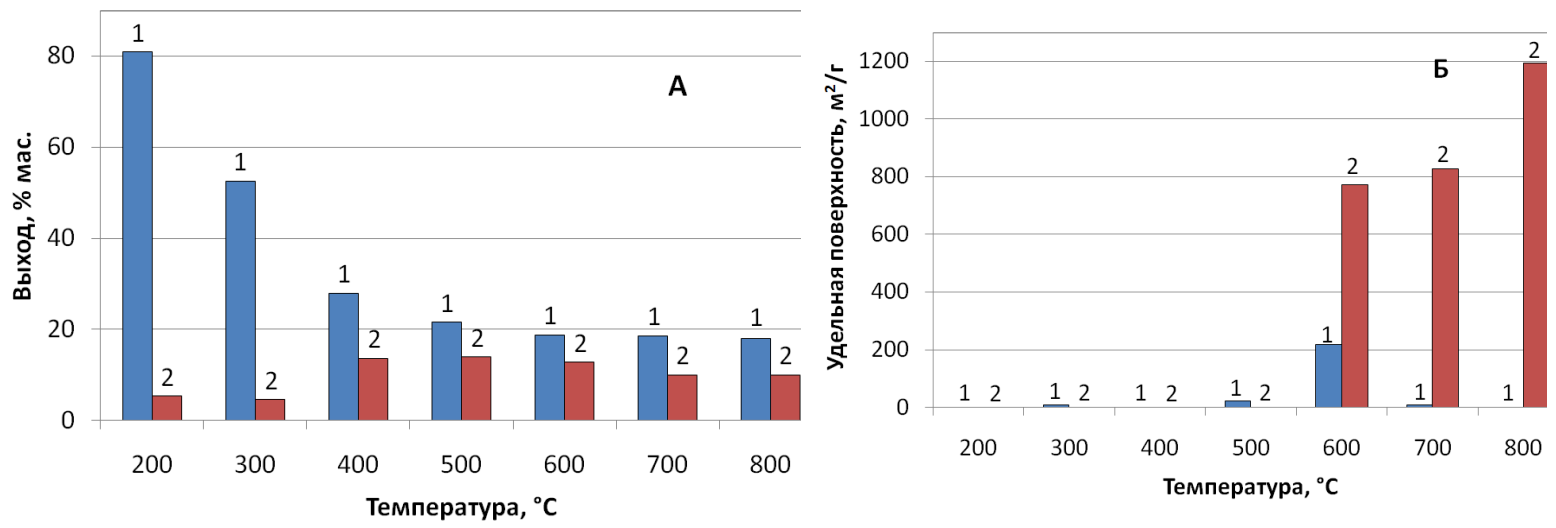

Рис. 3

Кузнецов Б.Н.др. 


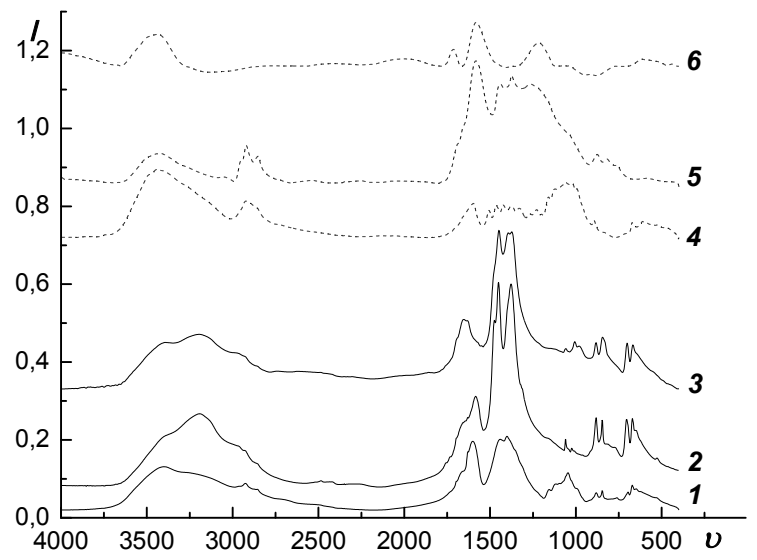

Pис. 4

Кузнецов Б.Н. и др. 

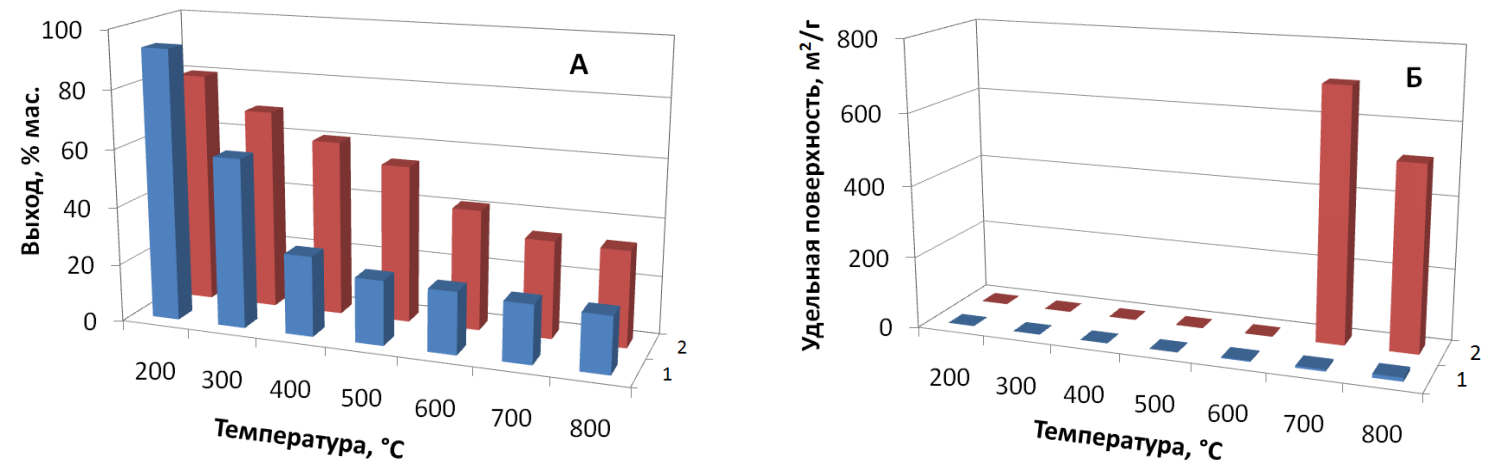

Рис. 5.

Кузнецов Б.Н. и др. 

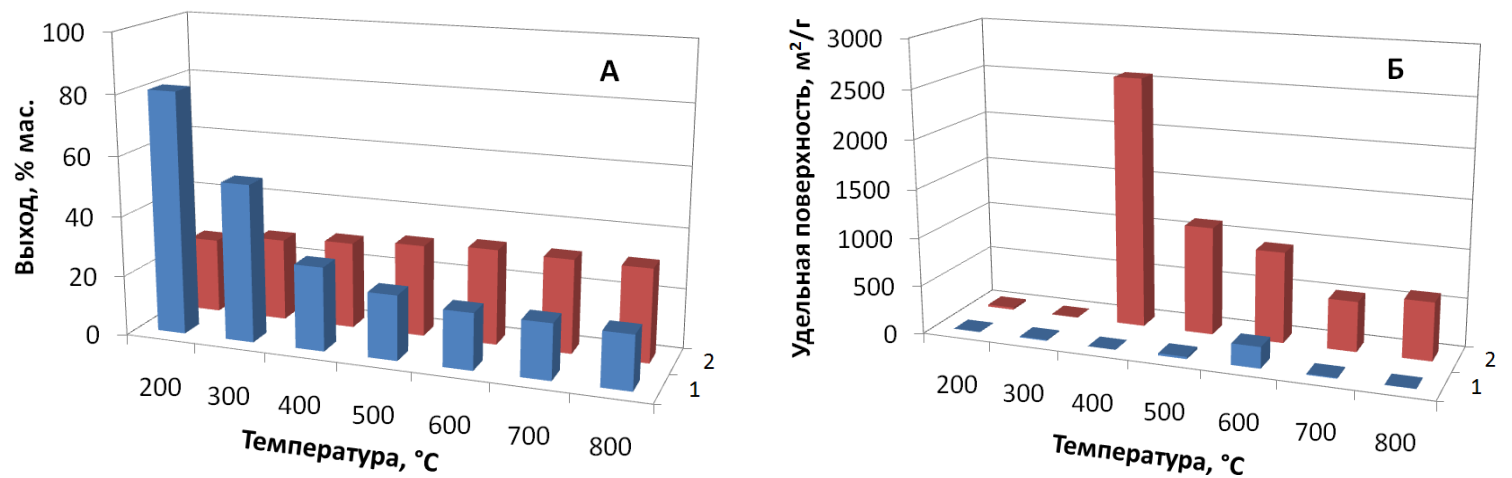

Рис. 6.

Кузнецов Б.Н. и др. 


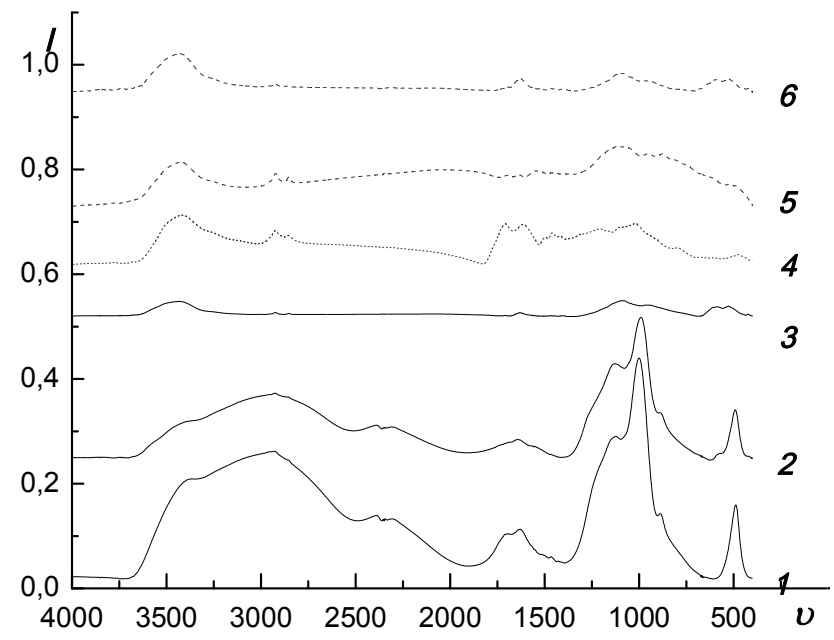

Рис. 7

Кузнецов Б.Н. и др. 